\title{
Analisis Perilaku Keselamatan Penggunaan Tabung Gas LPG pada Pekerja di Rumah Makan Warteg di Kelurahan Kalianyar Kecamatan Tambora Jakarta Barat
}

\section{Analysis of Safety Behavior Using LPG Gas Tube on Workers in Warteg Eating House in Kelurahan Kalianyar Kecamatan Tambora Jakarta Barat}

\author{
Muhammad Ridwan Alwi Nur Arrasyid, \\ Muhamad Arief Rahmadani, Mia Yulia Nurrizky \\ Program Studi Kesehatan Masyarakat Fakultas Ilmu-Ilmu Kesehatan \\ Universitas Muhammadiyah Prof. Dr. Hamka Jakarta \\ e-mail :miayulia28@gmail.com
}

\begin{abstract}
ABSTRAK
Liquified Petroleum Gas merupakan bentuk dari hasil konversi minyak tanah yang dibuat Pemerintah guna mengurangi pengeluaran APBN dalam hal pembelian bahan bakar. Maraknya penggunaan LPG di sektor rumah tangga serta kuliner seperti warteg menimbulkan beberapa kasus kebakaran karena kebocoran tabung gas akibat penggunaan LPG yang tidak aman yang salah satunya disebabkan oleh human factor. Tujuan penelitian ini adalah mengetahui bagaimana hubungan antara karakteristik (umur, pendidikan, masa kerja), pengetahuan, dan sikap pekerja warteg dengan penggunaan tabung gas LPG. Subyek peneitian ini adalah pekerja rumah makan warteg di Kelurahan Kalianyar, Jakarta Barat. Besar sampel dalam penelitian ini sebanyak 97 responden dengan menggunakan teknik quota sampling. Pengumpulan data dilakukan dengan mewawancara para responden dengan menggunakan lembar kuesioner. Hasil penelitian dari 73 responden menunjukkan bahwa 46,6 \% responden berperilaku tidak aman dalam penggunaan LPG dan 53,4\% responden berperilaku aman dalam penggunaan tabung LPG. Disamping itu, diperoleh hubungan antara perilaku keselamatan penggunaan tabung LPG pada pekerja rumah makan warteg dengan pengetahuan $(\mathrm{p}=0.000)$ dan sikap $(\mathrm{p}=0.047)$. Dapat disimpulkan bahwa pengetahuan dan sikap berpengaruh terhadap perilaku seseorang dalam menggunakan tabung gas LPG. Untuk meningkatkan perilaku aman pada pekerja sektor informal khususnya pekerja warteg, perlu dilakukan lagi sosialisasi dan penyebaran poster mengenai prosedur aman dalam penggunaan tabung gas LPG.
\end{abstract}

Kata Kunci : Perilaku aman, LPG, Pekerja warteg

\section{ABSTRACT}

Liquified Petroleum Gas is a kerosene's conversion product by The Government to decrease APBN expense. Unsafetyuse of LPG in the household and cullinary sector such as Warteg can cause several unintended consequences including fire cases due to leakage of gas cylinders as human error. This study aims to know the correlation between respondents characteristic (age, education, and time of work), knowledge, and employees behavior at eatery using LPG. The subject of this research was Warteg's employee in Kalianyar, Tambora Subdistrict, Jakarta Barat. Samples in this studywere 97 respondents using quota sampling. The data was collected by interviewing the respondents using questionnaire sheets. The result showed there was a correlation between knowledge $(p=0.000)$ and attitude $(p=0.047)$ with the use of liquid petroleum gas behavior. Itconcluded that knowledge and attitude take effect on the use of liquid petroleum gas behavior. To increase safe behavior especially Warteg'semployees, socialization and poster deployment about safe procedure in using liquid petroleum gas are needed.

Keywords: Safety Behavior, LPG abuse, unintended consequence, Warteg's employee 


\section{PENDAHULUAN}

Dalam upaya meningkat produktivitas dan efektivitas biaya dengan menekan anggaran belanja negara (APBN), pemerintah telah mengimplementasikan program konversi minyak tanah menjadi liquified petroleum gas (LPG) sebagai bahan bakar baik rumah tangga ataupun di segala segmen industri, termasuk pada rumah makanwarung tegal (warteg) sebagai industri usahamikro, kecil, dan menengah(UMKM). Namun, selain keuntungan yang didapat, timbul kejadian yang tidak diinginkan seperti kebakaran dan ledakan dapat menimbulkan kerugian materil dan non materil.

Faktor manusia (human error) sering menjadi penyebab kejadian tidak diinginkan dari penggunaan tabung gas LPG, seperti kurangnya pengetahuan serta sikap terkait kondisi aksesoris pendukung tabung gas LPG yang berstandar SNI, cara mendeteksi kebocoran tabung gas LPG, dan cara aman menggunakan tabung gas LPG (Lestari \& Hartono, 2011). Selain itu kerusakan LPG pada penggunanya dapat disebabkan oleh kurangnya sosialisasi mengenai penggunaan dan perawatan LPG (Latifah, dkk, 2015). Hal ini merupakan pemicu terjadinya peningkatan kasus kebakaran akibat tabung gas LPG.

Penggunaan LPG pada UMKMdi DKI Jakarta sendiri termasuk sebagai pengguna LPG tertinggi dengan 55.856.393 dan menduduki peringkat atas dengan persentase terbesar yaitu 98,77\% dari total UMKM (Kementerian Koperasi dan UKM, 2013). UMKM seperti warteg ini menjadi mata pencaharian masyarakat dan tersebar di seluruh DKI Jakarta.

Menurut data BPS tahun 2017 kepadatan penduduk di DKI Jakarta terbesar berada di wilayah Jakarta Barat yaitu sebesar 19.268,20/ $\mathrm{km}^{2}$. Dengan tingginya tingkat kepadatan penduduk, Jakarta Barat memiliki potensi sangat tinggi terdampak kejadian yang tidak diinginkan akibat penggunaanLPG yang tidak sesuai dibandingkan dengan wilayah Jakarta lainnya.

Daerah regional Jakarta Barat adalah sebuah kota administrasi di bagian Barat Daerah Khusus Ibu kota Jakarta. Memiliki luas 129.54 $\mathrm{Km}^{2}$ dengan persentase $19,56 \%$ dari total luas DKI Jakarta, jumlah populasi 2.496.002 dengan kepadatan 19.268,20 jiwa/ $\mathrm{km}^{2}$, Jakarta Barat terdiri dari 8 kecamatan dan 56 kelurahan. Jika dilihat kepadatan penduduk, Kecamatan Tambora menduduki peringkat pertama dengan jumlah yaitu sebesar $44.548 \mathrm{jiwa} / \mathrm{km}^{2}$ (BPS, 2017).
Kecamatan Tambora Jakarta Barat, sebagai salah satu wilayah yang cukup padat penduduknya. Hal tersebut dapat dibuktikan bahwa kelurahan kalianyar yang termasuk dalam kecamatan Tambora merupakan kelurahan terpadat se-Asia Tenggara (Maharani, 2011). Selain itu, maraknya usaha warteg yang ada di wilayah tersebut juga meningkatkan jumlah pengguna LPG di kawasan ini.

Masih kurangnya perhatian keselamatan kerja terutama pada sektor informal seperti pekerja rumah makan warteg menjadi satu hal yang perlu diperhitungkan. Terlebih lagi penggunaan tabung gas LPG pada rumah makan warteg memiliki masa pakai lebih boros dalam kesehariannya dibandingkan dengan sektor rumah tangga yanglebih sering mengalami penggantian tabung LPG. Perilaku ini rentan berpotensi menimbulkan kecerobohan pengguna (unsafe action) dalam menggunakan tabung gas LPG dan beresiko terjadinya ledakan serta kebakaran yang dapat merugikan diri sendiri maupun orang lain.

\section{SUBYEK DAN METODE}

Penelitian ini menggunakan metode analitik. Desain penelitian menggunakan Cross Sectional. Desain studi cross sectional ini dilakukan karena pengumpulan data variabel dependen dan indepeden dilakukan dalam waktu yang bersamaan.. Besar sampel dalam studi ini berjumlah 73 orang. Cara pengambilan sampel adalah dengan kuantum (quota sampling). Dalam hal ini sampel penelitian adalah pekerja warteg yang ada di wilayah Kelurahan Kalianyar Kecamatan Tambora Jakarta Barat. Kriteria inklusi pemilihan sampel adalah : 1) Pekerja yang bekerja di Warteg wilayah Kelurahan Kalianyar Kecamatan Tambora, 2) Pekerja yang berkaitan dengan pengolahan makanan di dapur, dan 3) Bersedia menjadi responden dalam penelitian.

Penelitian dilakukan pada tanggal 28 sampai 30 Mei 2018. Pengumpulan data dilakukan dengan mewawancara para responden dengan menggunakan lembar kuesioner. Pengolahan data dilakukan dengan analisis univariat dan bivariat. Untuk melihat karakteristik (umur, pendidikan, dan masa kerja), gambaran sikap, dan gambaran pengetahuan responden dilakukan analisis univariat. Analisis bivariat dilakukan untuk melihat hubungan antara karakteristik, sikap, dan pengetahuan responden dengan penggunaan tabung gas LPG. Analisis bivariat yang digunakan dalam penelitian ini adalah uji 
chi square. Beberapa variabel yang digunakan dalam penelitian ini yaitu penggunaan LPG (dikategorikan menjadi aman dan tidak aman), umur (dikategorikan menjadi tua ( $>40$ tahun) dan muda ( $\leq 40$ tahun)), pendidikan (dikategorikan menjadi $>6$ tahun dan $\leq 6$ tahun), pengetahuan (dikategorikan menjadi rendah dan tinggi), sikap (dikategorikan menjadi tidak baik dan baik.

\section{HASIL}

Dari 80 subyek, terdiri dari 73 pekerja warteg bersedia sedangkan 7 sisanya tidak bersedia menjadi sampel dalam penelitian ini. Karakteristik responden pada penelitian ini sebanyak 43 responden $(58,9 \%)$ berumur dibawah atau sama dengan 40 tahun dan terdapat 30 responden $(41,1 \%)$ berumur lebih dari 40 tahun. Pada variabel pendidikan distribusi responden paling banyak pada kelompok responden dengan tingkat pendidikan rendah atau tidak tamat sampai SMA yaitu sebanyak 56 responden
$(76,7 \%)$, kemudian sebanyak 17 responden $(23,2 \%)$ berada pada tingkat pendidikan tinggi yaitu sama atau diatas tamat SMA. Distribusi responden berdasarkan masa kerja, mayoritas memiliki masa kerja kurang atau sama dengan 6 tahun yaitu sebanyak 39 orang $(53,4 \%)$ dan sisanya sebanyak 34 orang $(46,6 \%)$ memiliki masa kerja lebih dari 6 tahun.

Terkait dengan penggunaan tabung gas LPG didapatkan hasil para pekerja masuk kategori aman sebesar 39 orang $(53,4 \%)$, dan kategori tidak aman sebesar 34 orang (46,6\%). Distribusi pada pengetahuan responden terkait tabung gas LPG didapatkan hasil responden dengan pengetahuan rendah yaitu sebanyak 37 orang $(50,7 \%)$ dan pengetahuan tinggi sebesar 36 orang (49,3\%). Distribusi responden dengan sikap tidak baik sebesar 36 responden atau sekitar 49,3\% sedangkan sikap baik sebesar 37 responden atau sekitar 50,7\% dari total responden.

Tabel 1. Distribusi Responden

\begin{tabular}{lcc}
\hline \multicolumn{1}{c}{ Variabel } & n & \% \\
\hline Umur & 30 & 41.1 \\
1. Tua $>40$ tahun & 43 & 58.9 \\
2. Muda $\leq 40$ tahun & & \\
Pendidikan & 56 & 76.7 \\
$\begin{array}{l}\text { 1. Rendah } \\
\text { 2. Tinggi }\end{array}$ & 17 & 23.3 \\
Masa Kerja & & \\
1. $>$ 6 tahun & 34 & 46.6 \\
2. $\leq 6$ tahun & 39 & 53.4 \\
$\begin{array}{l}\text { Penggunaan Tabung LPG } \\
\text { 1. Tidak Aman }\end{array}$ & & \\
2. Aman jika & & \\
Pengetahuan & 34 & 46.6 \\
1. Rendah & 39 & 53.4 \\
2. Tinggi & & \\
Sikap & 37 & 50.7 \\
1. Tidak baik & 36 & 49.3 \\
2. Baik & & \\
\hline & 36 & 49.3 \\
\hline
\end{tabular}


Tabel 2. Hasil uji hubungan (bivariat) pada variabel independen dan dependen

\begin{tabular}{|c|c|c|c|c|c|c|c|}
\hline \multirow{3}{*}{ Variabel Independen } & \multicolumn{4}{|c|}{ Penggunaan Tabung LPG } & \multirow{3}{*}{ OR } & \multirow{3}{*}{$\begin{array}{l}\text { 95\% CI Lower- } \\
\text { Upper }\end{array}$} & \multirow{3}{*}{ P Value } \\
\hline & \multicolumn{2}{|c|}{ Tidak Aman } & \multicolumn{2}{|c|}{ Aman } & & & \\
\hline & f & $(\%)$ & f & $(\%)$ & & & \\
\hline \multicolumn{8}{|l|}{ Umur } \\
\hline Tua ( $>40$ tahun) & 13 & 43.3 & 17 & 56.7 & 1.248 & $0.489-3.188$ & $* 3.881$ \\
\hline Muda ( $\leq 40$ tahun) & 21 & 48.8 & 22 & 51.2 & & & \\
\hline \multicolumn{8}{|l|}{ Pendidikan Terakhir } \\
\hline Rendah (Tidak tamat SMA) & 23 & 41.1 & 33 & 58.9 & 0.380 & $0.123-1.175$ & $* 0.087$ \\
\hline Tinggi (Tamat SMA) & 11 & 64.7 & 6 & 35.3 & & & \\
\hline \multicolumn{8}{|l|}{ Masa Kerja } \\
\hline Lama ( $>6$ tahun) & 17 & 50.0 & 17 & 50.0 & 0.773 & $0.307-1.945$ & $* 0.584$ \\
\hline Baru ( $\leq 6$ tahun) & 17 & 43.6 & 22 & 56.4 & & & \\
\hline \multicolumn{8}{|l|}{ Pengetahuan } \\
\hline Rendah & 27 & 73.0 & 10 & 19,4 & 11.186 & $3.727-33.568$ & $* * 0.000$ \\
\hline Tinggi & 7 & 19.4 & 29 & 80.6 & & & \\
\hline \multicolumn{8}{|l|}{ Sikap } \\
\hline Tidak Baik & 21 & 58.3 & 15 & 41.7 & 2.585 & $1.004-6.655$ & $* * 0.047$ \\
\hline Baik & 13 & 35.1 & 24 & 64.9 & & & \\
\hline
\end{tabular}

Keterangan :

*) Tidak Bermakna (P-value $>0.05)$

**) Bermakna (P-Value $<0.05)$

\section{Hubungan Umur dengan Penggunaan Tabung LPG}

Pekerja dengan umur "muda" memiliki proporsi penggunaan tabung gas LPG yang tidak aman paling tinggi yaitu sebanyak $48,8 \%$, dibandingkan dengan kelompok umur "tua" yaitu sebanyak 43,3\%. Sementara itu, pekerja yang memiliki umur "tua" lebih besar memiliki proporsi penggunaan tabung gas LPG yang aman yaitu sebesar $51,2 \%$, dibandingkan dengan umur "muda" yaitu sebesar 51,2\%. Hasil uji statistik diperoleh nilai p-value sebesar 3,881 yang berarti tidak ada hubungan yang bermakna antara umur dengan penggunaan tabung gas LPG. Berdasarkan hasil Odds Ratio (OR) responden yang memiliki umur tua beresiko 1,24 kali lebih besar untuk menggunakan tabung LPG tidak aman dibanding dengan responden yang memiliki umur muda.

\section{Hubungan Tingkat Pendidikan dengan Penggunaan Tabung LPG \\ Pekerja dengan tingkat pendidikan} "tinggi" memiliki proporsi penggunaan tabung gas LPG yang tidak aman paling tinggi (64,7\%), dibandingkan dengan kelompok pendidikan pekerja tingkat "rendah" dengan proporsi sebesar $41,1 \%$. Sementara itu, pekerja yang memiliki tingkat pendidikan "rendah" memiliki proporsi penggunaan tabung gas LPG yang aman lebih tinggi $(58,9 \%)$, dibandingkan dengan tingkat pendidikan "tinggi" (35,3\%). Diperoleh nilai p-value sebesar $0,087>0,05$ yang berarti tidak ada hubungan yang bermakna antara pendidikan dengan penggunaan tabung gas LPG. Hasil perhitungan Odds Ratio (OR) menunjukkan responden dengan pendidikan tinggi mencegah 0,38 kali lebih besar untuk menggunakan penggunaan tabung LPG tidak aman daripada responden yang memiliki pendidikan rendah.

\section{Hubungan Masa Kerja dengan Penggunaan Tabung LPG}

Pekerja dengan masa kerja "lama" memiliki proporsi penggunaan tabung gas LPG yang tidak aman lebih tinggi (50,0\%) dibandingkan dengan pekerja dengan masa kerja "baru" yaitu sebesar (43,6\%). Sementara itu, pekerja yang memiliki masa kerja "baru" lebih besar memiliki proporsi penggunaan tabung gas LPG yang aman yaitu sebesar $(56,4 \%)$, dibandingkan dengan masa kerja "lama" yaitu sebesar $(50,0 \%)$. Dengan nilai $p$-value sebesar $0,584>0,05$ menunjukan bahwa tidak ada hubungan yang bermakna antara masa kerja dengan penggunaan tabung gas LPG. Hasil perhitungan Odds Ratio (OR) menunjukkan responden dengan masa kerja lama mencegah 0,73 kali lebih besar berperilaku tidak aman dalam penggunaan tabung LPG daripada responden dengan masa kerja baru. 


\section{Hubungan Pengetahuan dengan Penggunaan Tabung LPG}

Berdasarkan tabel 2, diketahui bahwa pekerja dengan tingkat pengetahuan "rendah" memiliki proporsi penggunaan tabung gas LPG yang tidak aman paling tinggi (73,0\%), dibandingkan dengan kelompok pekerja dengan pengetahuan "tinggi" memiliki proporsi sebesar $19,4 \%$. Sementara itu, pekerja yang memiliki pengetahuan "tinggi" memiliki proporsi penggunaan tabung gas LPG yang aman lebih besar yaitu $80,6 \%$, dibandingkan dengan pekerja dengan tingkat pengetahuan "rendah" yaitu sebesar 19,4\%. Hasil uji statistik diperoleh nilai p-value sebesar $0,000<0,05$ yang berarti ada hubungan yang bermakna antara pengetahuan dengan penggunaan tabung gas LPG. Dari hasil perhitungan Odds Ratio (OR), responden dengan pengetahuan rendah berpeluang 11,186 kali lebih besar berperilaku tidak aman dalam penggunaan tabung LPG daripada responden dengan pengetahuan tinggi.

\section{Hubungan Sikap dengan Penggunaan Tabung LPG}

Sikap pekerja yang masuk kategori "tidak baik" memiliki proporsi penggunaan tabung gas LPG yang tidak aman paling tinggi dengan proporsi sebesar 58,3\%, dibandingkan dengan kelompok pekerja yang masuk dalam kategori "baik" dengan proporsi sebesar $35,1 \%$. Sementara itu, pekerja yang memiliki sikap "baik" lebih besar memiliki proporsi penggunaan tabung gas LPG yang aman yaitu sebesar $64,9 \%$, dibandingkan dengan sikap pekerja yang "tidak baik" yaitu sebesar $41,7 \%$. Hasil uji statistik diperoleh nilai $p$-value sebesar $0,047<0,05$ yang berarti ada hubungan yang bermakna antara sikap dengan penggunaan tabung gas LPG. Hasil perhitungan Odds Ratio (OR) menunjukkan responden dengan sikap tidak baik berpeluang 2,585 kali berperilaku tidak aman dalam penggunaan tabung LPG daripada responden dengan sikap baik.

\section{DISKUSI}

Penelitian menunjukkan bahwa pekerja warteg yang berada di Kelurahan Kalianyar mayoritas berusia kurang dari 40 tahun atau masuk dalam kategori "Muda" yaitu sebanyak 43 orang dan pendidikan mayoritas adalah kategori "Rendah" atau tidak tamat SMA yaitu sebanyak 56 orang. Sebanyak $46,6 \%$ pekerja masih menggunakan tabung LPG dengan tidak aman dikarenakan masih kurangnya pemahaman para pekerja rumah makan warteg dalam menggunakan tabung LPG secara baik dan benar.

Untuk analisis bivariat, ditemukan bahwa tidak ada hubungan yang bermakna antara umur, pendidikan terakhir, dan masa kerja dengan penggunaan tabung gas LPG. Adapun kriteria perilaku aman dalam penggunaan tabung gas LPG adalah yang penggunaannya sudah sesuai dengan pedoman penggunaan tabung gas LPG (Kementerian ESDM, 2017). Berdasarkan perbedaan resiko tanpa signifikansi, studi ini cenderung menemukan bahwa pekerja warteg yang berpendidikan tinggi memiliki perilaku tidak aman dalam penggunaan LPG dibandingkan dengan pekerja warteg yang memiliki pendidikan rendah $(\mathrm{OR}=0,380)$. Begitu pula pekerja warteg berusia lanjut dan masa kerja baru cenderung berperilaku tidak aman dalam penggunaan tabung LPG tidak aman, dibanding pekerja warteg berusia muda dan masa kerja lama dalam penggunaan tabung gas LPG.

Dan tingginya pengetahuan bukan menjadi faktor pendorong utama seseorang dapat menggunakan tabung gas LPG secara baik dan benar, masih terdapat faktor lain Studi ini menemukan bahwa pekerja warteg akan berperilaku aman dalam penggunaan LPG ketika masak apabila memiliki tingkat pengetahuan dan sikap yang baik. Pekerja warteg dengan tingkat pengetahuan dan sikap yang baik mengenai cara penggunaan tabung gas LPG, dengan mengetahui apa yang harus dilakukan dalam mencegah terjadinya kejadian yang tidak diinginkan dalam penggunaan LPG seperti ledakan dan kebakaran. Perilaku ini ditunjukkan mulai dari memeriksa aksesoris tabung gas LPG yang harus sesuai Standar Nasional Indonesia (SNI) dan keadaan tabung gas LPG pada saat pembelian tabung gas LPG. Perilakuini juga akan ditunjukkan dengan menggunakan LPG sebaik mungkin dengan efektif dan efisien (Pranadji, dkk, 2010). Studi ini dilakukan dengan desain potong lintang yang tidak dapat menjelaskan secara umum variabel yang diteliti sebagai sebab dalam status penggunaan tabung LPG karena tidak adanya relativitas sebab-akibat. Di sisi lain, analisis bivariat yang digunakan untuk mengukur penggunaan tabung diestimasi hanya dengan variabel itu sendiri (crude) tanpa disesuaikan dengan kondisi lain (unadjusted). Olehnya, tingginya pengetahuan bukan menjadi faktor 
pendorong utama seseorang dapat menggunakan tabung gas LPG secara baik dan benar, masih terdapat faktor lainnya yang dapatmendukung seperti fasilitas yang kurang memadai sebagai faktor pemungkin dan kebijakan kurang tepat gunas ebagai faktor penguat.

\section{KESIMPULAN}

Dari hasil penelitian dapat disimpulkan bahwa pengetahuan dan sikap berpengaruh terhadap perilaku seseorang dalam menggunakan tabung gas LPG. Oleh karena itu, agar meningkatkan perilaku aman pada pekerja sektor informal khususnya pekerja warteg, perlu dilakukan lagi sosialisasi dan penyebaran poster mengenai prosedur aman dalam penggunaan tabung gas LPG.

\section{UCAPAN TERIMAKASIH}

Kami ucapkan terimakasih untuk KEMENRISTEKDIKTI yang telah memberi dana hibah untuk kegiatan penelitian ini, kemudian kepada Bapak Awaludin Hidayat sebagai dosen pembimbing kami, serta mahasiswa FIKES Universitas Muhammadiyah Prof. DR HAMKA yang turut membantu dalam proses pengumpulan data.

\section{DAFTAR PUSTAKA}

Badan Pusat Statistik Kota Administrasi Jakarta Barat. (2017). Statistik Daerah Kota Jakarta dalam Infografis. Jakarta.

Kementerian ESDM RI Dirjen Minyak dan Gas Bumi. (2017). Pedoman Teknis Instalasi Pengisian, Penanganan dan Penggunaan Serta Pemeriksaan Berkala. Jakarta.

Kementerian Koperasi dan UKM. (2013). Perkembangan Data Usaha Mikro, Kecil, Menengah ( UMKM) dan Usaha Besar (UB) Perkembangan Data Usaha Mikro, Kecil, Menengah (UMKM) dan Usaha Besar (UB ). Jakarta.

Latifah, E. W., Hartoyo, \& Guhardja, S. (2015). Persepsi, Sikap , dan Strategi Koping Keluarga Miskin Terkait Program Konversi Minyak Tanah ke LPG di Kota Bogor, (July). https://doi. org/10.24156/jikk.2010.3.2.122

Lestari, F., \& Hartono, B. (2011). Peningkatan Pengetahuan dan Keterampilan Masyarakat tentang Cara Aman Menggunakan Tabung Gas $3 \mathrm{Kg}$ Knowledge and Skill Improvement on Society about $3 \mathrm{Kg}$ Gas Container, 225-229.

Maharani, E. (2011). Kelurahan Kalianyar Terpadat Se-DKI_Republika Online. Retrieved January 13, 1BC, from http://m.republika.co.id/berita/breaking-news/metropolitan/11/01/13/158088-kelurahan-kalianyar-terpadat-se-dki

Pranadji, D. K., Djamaludin, M. D., \& Kiftiah, N. (2010). Behaviour Analysis of Using the Household Fuel in Bogor, 3(2), 173-183. 